\title{
IMPACT IMPLEMENTATION OF PSAK 70 RELATED TO TAX AMNESTY ON REPORTING OF THE FIRM (CASE STUDY ON CV BTARI SENJA)
}

\author{
Widi Winarso', Rorim Panday ${ }^{2}$ \\ Economic Faculty of Bhayangkara Jaya University, Jakarta \\ widi.winarso@dsn.ubharajaya.ac.idindripan@gmail.com
}

\begin{abstract}
This study aims to test how big the impact of the application of PSAK (Statement of Financial Accounting Standards) 70 to the Financial Statement of CV Btari Senja before and after tax amnesty applied. The sampling technique used is the triangulation time technique (triangle time). The sample is determined using the credibility method. This research uses the data of CV Btari Senja Financial Report in 2015 and 2016. The results of this study stated that the application of PSAK 70 related tax amnesty greatly affect the Financial Statements at CV Btari Senja, especially in Reports of Debt and Assets.
\end{abstract}

Keywords: Tax Amnesty, Financial Reporting and its impact

\section{INTRODUCTION}

Taxes are an important source of state income for the implementation and welfare of the people. According to Prof. Dr. Rochmat Soemitro, SH (2013, in Mardiasmo h.1), Taxes are public dues to state coffers by force (law enforced) with no direct exposure (contra) services and which are used to pay public expenditures.

Domination of taxes in state revenues should be welcomed, because through the tax independence of the state in finance the development and government is expected to be achieved. All costs of development and development undertaken by the state come from the community itself, not from the help of other countries. This situation has an impact on the independence of a stronger state so that the state does not depend on other countries in financing the development within the country. This 
shows that tax revenues have a strategic role that should get important attention from the government. State revenue from the tax sector is the largest state revenue. This is evidenced by the State Budget in 2015 as shown in Table 1.

Table 1.State Budget in the 2015 State Budget

\begin{tabular}{|c|c|c|}
\hline Description & $\begin{array}{c}\text { of Number (in trillion } \\
\text { Rupiah) }\end{array}$ & of Persentage \\
\hline Taxes & $1.489,3$ & $83,0 \%$ \\
\hline Revenue Country not Tax & 269,1 & $15,0 \%$ \\
\hline Grants & 3,3 & $0,2 \%$ \\
\hline Total & $1.793,6$ & $100 \%$ \\
\hline
\end{tabular}

The data in Table 1 shows that the state revenue from the tax sector contributes $83 \%$ to the total state budget of $\operatorname{Rp} 1,489.3$ trillion. Tax revenues in the 2015 State Budget amounting to Rp 1489.3 trillion was an increase of $29.9 \%$ compared to actual tax revenues in 2014 as shown in Table 2.

Table2 Growth of Tax Receipts from 2010 - 2015

\begin{tabular}{|c|c|c|c|}
\hline \multirow{2}{*}{ Year } & amount & Increase & Percentase \\
\cline { 2 - 4 } & (in Trillion Rupiah) & (in Trillion Rupiah & Increase \\
\hline $\mathbf{2 0 1 0}$ & 649,0 & - & - \\
\hline $\mathbf{2 0 1 1}$ & 837,9 & 188,8 & $20,8 \%$ \\
\hline $\mathbf{2 0 1 2}$ & 980,5 & 142,6 & $12,2 \%$ \\
\hline $\mathbf{2 0 1 4}$ & $1.077,3$ & 96,8 & $9,9 \%$ \\
\hline $\mathbf{2 0 1 5}$ & $1.146,5$ & 69,2 & $9,9 \%$ \\
\hline
\end{tabular}

Source: Ministry of Finance of the RepublicIndonesia, 2015

The data in Table 2 shows that the increase in tax revenue of $29.9 \%$ represents the largest tax revenue target increase in the last 5 years. The increase in revenue 
target of $29.9 \%$ is due to the current government funding requirement to implement government policy.

The standard of living of the community will increase, it is necessary to increase the budget. This can be seen from the size of the Indonesian government budget for 2011. The 2011 State Budget Expenditures of Rp1,229.6 trillion increased from the year 2010 which amounted to Rp1.126 Trillion only. While in 2012, tax revenue is targeted at $\mathrm{Rp} 1,032.6$ trillion.

State revenues from year to year always increase, however, the opportunity to be improved in the future is wide open because the potential has not been optimally explored. However, the problem is that some of the property outside the territory of the Unitary State of the Republic of Indonesia has not been reported by the owner of the property in his Income Tax Form so that there may be tax consequences which may arise if possible compared to the assets already reported in the Annual Tax Return Income Tax concerned. (Indra Mahardika, 2017, p.118).

To extract state revenues from the tax sector, real efforts are needed, and implemented in the form of government policies. These efforts can be either intensification or extensification of taxation. Tax intensification can be an increase in the number of Taxpayers (WP) as well as increased tax revenue itself. Extensification efforts can be extensions of tax objects that have not been explored. To pursue tax revenues, it is necessary to support a stable political socioeconomic situation, so that people can also voluntarily pay their taxes. The government is certainly expected to reconsider taxation policies that can attract public interest into taxpayers such as sunset policy.

Likewise, one of the necessary policies considered is the granting of a Tax amnesty. This policy is expected to increase tax subject and tax object. The subject of tax can be the return of funds abroad, while from the side of the tax object in the form of additional taxpayers. (Ragimun, 2015)

One of the efforts made by the government to increase tax revenue is by applying the policy of tax amnesty. This is in accordance with the Law of the 
Republic of Indonesia Number 11 Year 2016 About Tax Amendment that one of the purposes of amnesty tax amnesty is to increase tax revenue, which will be used for development financing.

In the Law of the Republic of Indonesia Number 11 of 2016 on Tax Amnesty, tax pardon or tax amnesty is the abolition of taxes that should be payable, not subject to sanctions of tax administration and criminal sanctions in the field of taxation, by disclosing property and paying ransom as stipulated in law - this invite. Implementation of tax amnesty policy is expected to be increasing people's willingness to pay taxes. Tax amnesty is implemented based on the principle of legal certainty, justice, benefit, and national interest. It is in accordance with that expressed by Purnawati (2014) that the ideal tax system for a country must have a principle of benefits (benefits principle) is expected far greater benefits than the tax that must have the principle of equity (equity principle).

Relationship tax amnesty with tax revenue refers to research conducted by Ngadiman and Huslin (2015), which indicates that the tax amnesty has a positive and significant effect on taxpayer compliance. If the application of tax amnesty is higher, then taxpayer compliance is also higher. PSAK 70 is effective from the date of ratification of the Tax Forgiveness Law with the transitional provisions of the entity choosing accounting policies pursuant to paragraph apply the provisions of PSAK 25: Accounting Policies, Changes in Accounting Estimates, and Errors. Whereas the entity chooses accounting policies pursuant to paragraph 07 applying PSAK 70 prospectively.

As we know PSAK 70 is a transition from PSAK 25 which in paragraph 06 which reads "Assessment whether an omission to include or error in recording can affect the user's economic decisions, and become material, require consideration of the characteristics of the user. The basic framework for the preparation and presentation of the Financial Statements paragraph 25 states "the user is assumed to have adequate knowledge of economic and business activities, accounting, and willingness to, learn information with reasonable diligence". Therefore, the 
assessment needs to consider how the intended users are expected to be rationally influenced in economic decision making. "

\section{THEORETICAL FRAMEWORK}

According Rahayu (2010) in the discussion of Tax Amendment or tax amnesty. Describe some reasons why Tax Remissions need to be done. The first is Underground economic is part of economic activity that is deliberately hidden to avoid tax payments, which take place in all countries, both developed and developing countries. This economic activity is usually measured by the amount of economic value generated. Compared with the value of gross domestic product (GDP). Based on the research of Dr. Enste and Dr Schneider (2002), the magnitude of the percentage of underground economic activities in developed countries can reach $14-16 \%$ of GDP.

This underground economic activity was never reported as income in the income tax return form (SPT) of Income Tax, which is included in the tax evasion criteria. The increase in the underground economy coupled with tax-smuggling is very detrimental to the State because it means the loss of tax money that is urgently needed to finance education programs, healthcare, and other poverty alleviation programs. Hence the idea arises to recover unpaid taxes from underground economic activities through a special program of tax forgiveness (Erwin Silitonga, in Siti Kurnia Rahayu, 2010). The second is Illegal Capital Officialization. Tax amnesty policy is the government's last attempt to increase the amount of tax revenue, because the government has difficulty withdrawing funds or capital that has been brought or parked abroad.

Existing domestic legal instruments have limitations that can not reach Taxpayers who are illegally saving funds abroad (John Hutagaol, in Siti Kurnia Rahayu, 2010). The third is Financial Transaction Engineering resulting in the loss of potential tax revenues. Advances in infrastructure and international financial instruments such as tax heaven and derivate transactions have encouraged large 
companies to engage in illegal profit shifting abroad by means of engineering financial transactions. After that the profits brought abroad some of them go back to Indonesia in the form of foreign loans or foreign investment. This transaction is called money laundering. Domestic tax provisions are not able to tax the engineering of these financial transactions. If this is not resolved soon, there will be a significant loss of tax potential.

Tax amnesty is expected to increase awareness of Taxpayer by giving opportunity for him to become obedient Taxpayer (John Hutagaol in Siti Kurnia, 2010). According to Indra Mahardika (2017, h 123) Every Taxpayer is entitled to a tax pardon. However, in this case a Taxpayer who has an Annual Income Tax Return whether for those who already have NPWP or who do not have NPWP. Therefore Taxpayers are solely only required to withhold or tax collection such as government treasurers is not eligible for tax amnesty. Then for a Taxpayer who does not have a Taxpayer Identification Number (NPWP), the method must register first to obtain NPWP at the Tax Office whose working area covers the residence or the status of the Taxpayer concerned.

\section{RESEARCH METHODS}

In this study the researchers focused more on the triangulation of time in because of the Financial Statements received in view based on time, namely the Financial Statements obtained from the period of December 31, 2015 to December 31, 2016. Based on the data in which time triangulation can be applied in because the Tax Force itself is enforced in the period 2016 - 2017, it shows that time triangulation is more appropriately used in this study.

\section{ANALYSIS AND DISCUSSION}

In the Debt Report of CV. Btari Senja in the period of December 31, 2015 is not listed. However, after the Tax pardon, the Financial Statements for the period of 
December 31, 2016 The Company's debt is reported in accordance with SFAS No. 70 paragraph 09, the entity shall recognize the tax payable assets and liabilities if the recognition of such assets and liabilities is indicated by IFRSs. An entity does not recognize an item as a tool and a liability, if SAK does not allow recognition of the item.

With the recognition of the researcher company concluded that CV. Btari Senja experiencing changes in the Financial Statements, especially on the company's debt report. And from PSAK 70 related tax amnesty the application of financial reporting is very big effect.

While in the report of Property Assets CV. Btari Senja has performed in accordance with PSAK 70 related assets as in paragraph 10 on the title Measurement At the Early Measurement which reads "tax forgiveness is measured at the cost of tax forgiveness assets as defined in paragraph 05." the tax forgiveness asset is deemed cost and becomes the basis for the entity in performing the measurement after initial recognition pursuant to paragraph 15 ". And in paragraph 15 it reads "the measurement after the initial recognition of the tax payable assets and liabilities refers to the relevant IFRSs, including, but not limited to:

a. Investment properties, in accordance with PSAK 13: Investment Property

b. Inventories, in accordance with PSAK 14:Inventories

c. Investments in joint venture and joint ventures, in accordance with PSAK 15: Investments in Associated Entities and Joint Venture

d. Fixed assets, in accordance with PSAK 16:Property, plant and equipment

e. Intangible assets, in accordance with PSAK 19: Intangible assets

f. Financial Instruments, in accordance withPSAK55 : Financial Instruments : Recognition and Measurement.

And in the Financial Position Report of CV. Btari Senja for the period of December 31, 2016 and The Financial Position Report of CV. Btari Senja period 31 December 2015 difference in total Assets for December 31, 2016 amounting to Rp 
883,189,797 while in period of 31 December 2015 amounting to Rp 776,345,748 the difference in Assets amounting to $\operatorname{Rp} 106,844,049$.

From these data it can be concluded that in the period of 31 December 2015 before reporting of Tax Amendment or tax amnesty applied assets in the company amounted to $\mathrm{Rp} 776,345,748$. Then in the December 31, 2016 Period increased by Rp 883.189.797, from the data stated that in reporting tax amnesty all assets including assets of the company must be reported in all. From 2015 only a few assets were reported in 2016 and increased in 2016, as stated in PSAK 70 in paragraph 19 on the presentation of assets which reads "Assets and liabilities of tax forgiveness are presented separately from assets and liabilities in the statement of financial position, if the entity chooses an accounting policy pursuant to paragraph 07, but does not apply paragraphs 16 and 17. If an entity presents current assets and non-current assets as well as short- and long-term liabilities as a classification of both current and non-current tax payable and short-term tax forgiveness liabilities and long term if, and only if, the entity has sufficient information to separating the classification. If the classification of the classification is arbitrary, the entity presents the tax payable assets and liabilities as part of its non-current assets and long-term liabilities in the statement of financial position. "And in the 20th paragraph it reads: The entity reclassifies the previously presented tax assets and liability assets in accordance with paragraph 19, into the heading of similar assets and liabilities, when: (a) The entity shall reassess the tax remuneration assets and liabilities pursuant to paragraph 16; or (b) The entity obtains control over the investee under paragraph 17.

The entity restates the nearest financial statements, only if the date of the financial statements is after the date of the Certificate.

Paragraph 21 reads: The entity does not offset between tax payable assets and liabilities.

And from the comparison results can be concluded that the PSAK 70 tax amnesty is very influential on financial reporting at CV. Btari Senja. 


\section{CONCLUSIONS AND SUGGESTIONS}

Based on data analysis and discussion that has been done then it can be concluded as follows:

1. Based on the credibility test of the impact of PSAK 70 relating tax amnesty to the Financial Statement, explains that PSAK 70 affects financial reporting, especially in the report of Company Debt and Company Assets in accordance with PSAK in paragraphs 09 and 10.

2. CV. Btari Senja has applied PSAK 70 well as stated in PSAK 70 paragraph Paragraph 22 reads:"The entity discloses, in its financial statements, the date of the Certificate and the amounts recognized as tax forgiveness assets based on the Certificate, as well as the amount of tax payable liability". And paragraph 23 reads: "Entities use its consideration in disclosing accounting policies and estimates, as well as details of the carrying amount that have a significant impact on the financial statements to produce relevant and reliable information".

3. And in the Transitional Provisions of the PSAK of paragraph 24 which reads "the entity applies the provisions of PSAK 25: Accounting Policies, Changes in Accounting Estimates, and paragraphs 41-53, if the entity chooses an accounting policy pursuant to paragraph 06 . The results of research on the effect of the application of PSAK 70 related tax amnesty to the reporting agency in this company is expected to give the following implications:

1) For the company

The results of this study can be used as a consideration in the application of PSAK 70 to the Financial Statements in the company. So from the Tax amnesty, it is expected that the Financial Report in the company, especially in financial management, can re-arrange and review the Financial Statements at CV. Btari Senja so that the Financial Report can be a reference to further advance the company especially in the addition of Assets 
2) For academics

The results of this study can be used as a comparison and reference material for further research and are expected to continue research related to the Application of PSAK 70 related Tax Amnesty in a company / entity

3) For Research

This research makes the insights of researchers become more widespread in because of the knowledge of Tax Amnesty (tax amnesty) was increased. And also researchers are more aware of the impact of the Tax on State.

\section{REFERENCES}

Dwi Martiani, Sylvia Veronica NPS, Ratna Wardhani, Aria Farahmita, Edward Tanujaya. Taufik Hidayat.2015. Akuntansi Keuangan Menengah Berbasis Psak. Edisi: 2. Jakarta. Salemba Empat.

H.Eddy Faisal, Se., Sh., M.M., M.Ak., B.K.P., C.P.M.A. Rento Akhiatri, S.E. 2016. Memahami Amnesty Pajak Dengan Cerdas Dan Lengkap. Jakarta. Buku Pintar Indonesia.

Hery, Se, Msi. 2012. Pengantar Akuntansi 1. Edisi: Revisi. Cetakan-2. Jakarta. Lembaga Penerbit Fakultas Ekonomi Universitas Indonesia.

IAI (Ikatan Akuntan Indonesia). 2012. Standart Akuntansi Keuangan Per 1 Juni 2012. Edisi: Revisi. Jakarta. Ikatan Akuntan Indonesia.

IAI (Ikatan Akuntan Indonesia). 2015. Susunan Dalam Satu Naskah Undang-Undang Perpajakan. Cetakan ke-29. Jakarta. Ikatan Akuntan Indonesia.

IAI (Ikatan Akuntan Indonesia). 2017. Standart Akuntansi Keuangan Per 1 Januari 2017. Edisi: Revisi. Jakarta. Ikatan Akuntan Indonesia.

Indra Mahardika Putra. 2017. Perpajakan. Edisi: Tax Amnesty. Cetakan-1. Yogyakarta. Quadrant.

Kadek D.P, I Gusti A.P, Dan Made Arie W. 2017. Pengaruh Tax Amnesty, Pertumbuhan Ekonomi, Kepatuhan Wajib Pajak, Dan Transformasi Kelembagaan Direktorat Jenderal Pajak 2015 Di Kantor Pelayanan Pajak Pratama Singaraja. E-Journal S1 Ak Universitas Pendidikan Ganesha Jurusan Akuntansi Program S1 (Volume 7 No.1 Tahun 2017).

Prof. Dr. Mardiasmo. 2013. Perpajakan. Edisi: Revisi. Yogyakarta. Andi Yogyakarta.

Prof. Dr. Sugiyono. 2016. Metode Penelitian Kombinasi (Mixed Methode). Cetakan Ke-3. Bandung. Alfabeta.

Ragimun Abdullah. 2015. Analisis Implementasi Pengampunan Pajak (Tax Amnesty) Di Indonesia. www.kemenkeu.go.id

Siti Kurnia Rahayu. 2010. Perpajakan Indonesia Konsep Dan Aspek Formal. Yogyakarta. Graha Ilmu. Online. 
Syarifudin Sukri, Se. Ak., Ca. B.K.P. 2016. Panduan Komprehensif Tax Amnesty +135 Kasus. Jakarta. Amnesty Pajak.

Waluyo. 2014. Akuntansi Pajak. Edisi: 5. Jakarta. Salemba Empat.

Wijaya, Tony. Metodologi Penelitian Ekonomi dan Bisnis; Teori dan Praktik. Yogyakarta: Graha Ilmu, 2013. Online. 